\title{
Palladium and platinum complexes of 2-(2'-carboxyphenylazo)-4- methylphenol: Synthesis, structure and spectral properties
}

\author{
SARMISTHA HALDER ${ }^{\mathrm{a}}$, MICHAEL G B DREW ${ }^{\mathrm{b}}$ and SAMARESH BHATTACHARYA ${ }^{\mathrm{a}, *}$ \\ ${ }^{a}$ Department of Chemistry, Inorganic Chemistry Section, Jadavpur University, Kolkata 700032 \\ ${ }^{b}$ Department of Chemistry, University of Reading, Whiteknights, Reading RG6 6AD, UK \\ e-mail: sbhattacharya@chemistry.jdvu.ac.in
}

MS received 14 July 2008; revised 30 July 2008

\begin{abstract}
Reaction of 2-(2'-carboxyphenylazo)-4-methylphenol $\left(\mathrm{H}_{2} \mathrm{~L}\right)$ with $\left[\mathrm{M}\left(\mathrm{PPh}_{3}\right)_{2} \mathrm{Cl}_{2}\right](\mathrm{M}=\mathrm{Pd}, \mathrm{Pt})$ affords mixed-ligand complexes of type $\left[\mathrm{M}\left(\mathrm{PPh}_{3}\right)(\mathrm{L})\right]$. Structures of both the complexes have been determined by X-ray crystallography. Both the complexes are square planar, where the 2-(2'-carboxyphenylazo)-4-methylphenol is coordinated to the metal center, via dissociation of the two acidic protons, as a dianionic tridentate $\mathrm{O}, \mathrm{N}, \mathrm{O}$-donor, and the fourth position is occupied by the triphenylphosphine. These complexes show intense MLCT transitions in the visible region.
\end{abstract}

Keywords. 2-(2'-carboxyphenylazo)-4-methylphenol; palladium and platinum complexes; crystal structure; spectral properties.

\section{Introduction}

There has been considerable current interest in palladium and platinum complexes, largely because of their potential catalytic and biological applications. ${ }^{1}$ As properties of such complexes depend primarily on the coordination environment around the metal center, complexation of these metals by ligands of selected types is of significant importance. For the present study we have selected 2-(2'-carboxyphenylazo)-4-methylphenol (1) as the principal ligand. Ligand 1 has been abbreviated as $\mathrm{H}_{2} \mathrm{~L}$, where $\mathrm{H}_{2}$ stands for the two potentially dissociable protons,

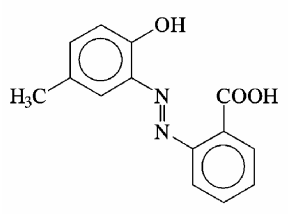

1

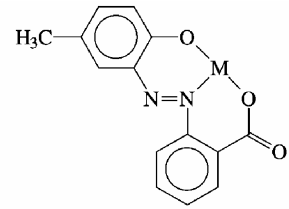

2

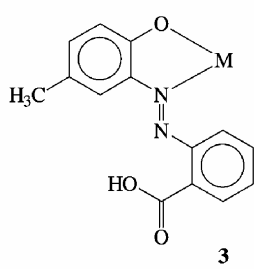

viz. the phenolic proton and the carboxylic proton This ligand has three types of potential donor sites,

\footnotetext{
*For correspondence
}

viz. the phenolate oxygen, the azo nitrogens and the carboxylate oxygens. However, this ligand has been observed to display different modes of coordination in its complexes. It is known to bind to metal ions as a dianionic tridentate $\mathrm{O}, \mathrm{N}, \mathrm{O}$-donor (2) utilizing all the three types of donor atoms forming two adjacent six-membered chelate rings. ${ }^{2}$ It has also been observed to coordinate metal ion as a monoanionic bidentate N,O-donor (3) utilizing the phenolate oxygen and the first azo-nitrogen forming a five-membered chelate ring. ${ }^{3}$ In this latter coordination mode (3) the carboxylate oxygens are disposed so far away from the metal center that none of them can participate in the coordination. To interact with ligand $\mathbf{1}$ two reactive complexes of palladium and platinum, viz. trans$\left[\mathrm{Pd}\left(\mathrm{PPh}_{3}\right)_{2} \mathrm{Cl}_{2}\right]$ and cis-[ $\left.\mathrm{Pt}\left(\mathrm{PPh}_{3}\right)_{2} \mathrm{Cl}_{2}\right]$ have been chosen. The primary objective of the present study has been to synthesize mixed-ligand complexes of the two metals incorporating ligand $\mathbf{1}$ and find out the coordination mode of ligand $\mathbf{1}$ in them. Reactions of ligand 1 with the chosen palladium and platinum compounds have indeed afforded mixed-ligand complexes of type $\left[\mathrm{M}\left(\mathrm{PPh}_{3}\right)(\mathrm{L})\right](\mathrm{M}=\mathrm{Pd}$ and $\mathrm{Pt})$, in which ligand 1 has been found to bind the metal centers in the tridentate fashion (2). The chemistry of these two complexes is described in this paper with special reference to their synthesis, structure and spectral properties 


\section{Experimental}

\subsection{Materials}

Palladium chloride and chloroplatinic acid were obtained from Arora Matthey, Kolkata. Triphenylphosphine, para-cresol and anthranilic acid were purchased from $\mathrm{E}$ Merck, India. The trans$\left[\mathrm{Pd}\left(\mathrm{PPh}_{3}\right)_{2} \mathrm{Cl}_{2}\right]$ and cis-[Pt( $\left.\left(\mathrm{PPh}_{3}\right)_{2} \mathrm{Cl}_{2}\right]$ complexes were prepared by following reported procedures. ${ }^{4}$ The 2-(2'-carboxyphenylazo)-4-methylphenol ligand was prepared by coupling diazotized anthranilic acid with para-cresol. All other chemicals and solvents were reagent-grade commercial materials and were used as received.

\subsection{Synthesis of $\left[P d\left(P P h_{3}\right)(L)\right]$}

To a solution of 2-(2'-carboxyphenylazo)-4-methylphenol $(40 \mathrm{mg}, 0.16 \mathrm{mmol})$ in ethanol $(40 \mathrm{~mL})$ was added trans-[Pd($\left.\left(\mathrm{PPh}_{3}\right)_{2} \mathrm{Cl}_{2}\right](100 \mathrm{mg}, 0.14 \mathrm{~mol})$ followed by triethylamine $(35 \mathrm{mg}, 0.35 \mathrm{mmol})$. The resulting mixture was then heated at reflux for $4 \mathrm{~h}$ to yield a reddish-purple solution. The solvent was then evaporated to give a solid mass, which was subjected to purification by thin layer chromatography on a silica plate. With 1:40 acetonitrile-benzene as the eluant a reddish-purple band separated, which was extracted with 1:1 dichloromethane-acetonitrile.
Evaporation of this extract gave $\left[\mathrm{Pd}\left(\mathrm{PPh}_{3}\right)(\mathrm{L})\right]$ as a dark crystalline solid. Yield: $67 \%$.

Analysis: Calc. for $\mathrm{C}_{32} \mathrm{H}_{25} \mathrm{~N}_{2} \mathrm{O}_{3} \mathrm{PPd}$ : C, 61.69; H, $4.02 ; \mathrm{N}, 4.50 \%$. Found: C, 61.03; H. 4.04; N, 4.66\%.

\subsection{Synthesis of $\left[P t\left(\mathrm{PPh}_{3}\right)(L)\right]$}

This complex was obtained as a violet crystalline solid by following the same above procedure using cis- $\left[\mathrm{Pt}\left(\mathrm{PPh}_{3}\right)_{2} \mathrm{Cl}_{2}\right]$ instead of trans $-\left[\mathrm{Pd}\left(\mathrm{PPh}_{3}\right)_{2} \mathrm{Cl}_{2}\right]$. Yield: $70 \%$.

Analysis: Calc. for $\mathrm{C}_{32} \mathrm{H}_{25} \mathrm{~N}_{2} \mathrm{O}_{3} \mathrm{PPt}$ : C, 54.00; H, 3.52 ; N, 3.94\%. Found: C, 54.79; H. 3.44; N, 4.01\%.

\subsection{Physical measurements}

Microanalyses $(\mathrm{C}, \mathrm{H}, \mathrm{N})$ were done using a Heraeus Carlo Erba 1108 elemental analyzer. NMR spectra in $\mathrm{CDCl}_{3}$ solutions were recorded on a Bruker Avance 300 NMR spectrometer. IR spectra were obtained on a Perkin-Elmer 783 spectrometer with samples prepared as $\mathrm{KBr}$ pellets. Electronic spectra were recorded on a JASCO V-570 spectrophotometer.

\section{$2.5 X$-ray crystallographic analysis for complexes $\left[P d\left(P P h_{3}\right)(L)\right]$ and $\left[P t\left(P P h_{3}\right)(L)\right]$}

Single crystals of $\left[\mathrm{Pd}\left(\mathrm{PPh}_{3}\right)(\mathrm{L})\right]$ and $\left[\mathrm{Pt}\left(\mathrm{PPh}_{3}\right)(\mathrm{L})\right]$ were obtained by slow evaporation of a solution of

Table 1. Summary of structure determination of $\left[\mathrm{Pd}\left(\mathrm{PPh}_{3}\right)(\mathrm{L})\right]$ and $\left[\mathrm{Pt}\left(\mathrm{PPh}_{3}\right)(\mathrm{L})\right]$.

\begin{tabular}{lll}
\hline Formula & $\mathrm{C}_{32} \mathrm{H}_{27} \mathrm{~N}_{2} \mathrm{O}_{4} \mathrm{PPd}$ & $\mathrm{C}_{33} \mathrm{H}_{26.5} \mathrm{~N}_{2 \cdot 5} \mathrm{O}_{3} \mathrm{PPt}$ \\
Formula weight & $640 \cdot 93$ & $732 \cdot 12$ \\
Crystal system & Triclinic & Triclinic \\
Space group & $\mathrm{P} \overline{1}$ & $\mathrm{P} \overline{1}$ \\
$Z$ & 2 & 2 \\
$a(\AA)$ & $8 \cdot 9220(8)$ & $8.9281(8)$ \\
$b(\AA)$ & $12 \cdot 1191(8)$ & $12 \cdot 2229(8)$ \\
$c(\AA)$ & $14 \cdot 0058(9)$ & $14 \cdot 1454(9)$ \\
$\alpha\left({ }^{\circ}\right)$ & $74 \cdot 078(6)$ & $73 \cdot 643(6)$ \\
$\beta\left({ }^{\circ}\right)$ & $83 \cdot 647(7)$ & $83 \cdot 715(7)$ \\
$\gamma\left({ }^{\circ}\right)$ & $69 \cdot 911(8)$ & $69 \cdot 359(8)$ \\
$V\left(\AA^{3}\right)$ & $1367 \cdot 47(19)$ & $1386 \cdot 0(2)$ \\
$\mu\left(\mathrm{mm}^{-1}\right)$ & $0 \cdot 778$ & $5 \cdot 159$ \\
$\mathrm{Crystal}$ size $\left(\mathrm{mm}^{3}\right)$ & $0 \cdot 15 \times 0 \cdot 20 \times 0 \cdot 25$ & $0 \cdot 05 \times 0.05 \times 0.30$ \\
$T(\mathrm{~K})$ & 150 & 150 \\
$D_{\text {call }}\left(\mathrm{g} / \mathrm{cm}^{3}\right)$ & 1.557 & 1.754 \\
$\lambda(\AA)$ & $0 \cdot 71073$ & 0.71073 \\
No. of reflections measured & 9583 & 10658 \\
No. of unique reflections & 7628 & 8833 \\
$R_{1}$ indices $(F>4 \sigma(F))$ & $0 \cdot 0707$ & $0 \cdot 0679$ \\
$w R_{2}$ & $0 \cdot 1976$ & $0 \cdot 1745$ \\
GOF & $0 \cdot 99$ & $1 \cdot 06$ \\
\hline
\end{tabular}


the complex in $1: 1$ dichloromethane-acetonitrile. Selected crystal data and data collection parameters are given in table 1. Data were collected on a Marresearch Image Plate system using graphite monochromated $\operatorname{MoK} \alpha$ radiation. X-ray data reduction and, structure solution and refinement were done using SHELXS-97 and SHELXL-97 programs. ${ }^{5}$ The structures were solved by the direct methods.

\section{Results and discussion}

\subsection{Synthesis and structure}

Reaction of 2-(2'-carboxyphenylazo)-4-methylphenol $\left(\mathrm{H}_{2} \mathrm{~L}, 1\right)$ with trans-[ $\left.\mathrm{Pd}\left(\mathrm{PPh}_{3}\right)_{2} \mathrm{Cl}_{2}\right]$ proceeds smoothly

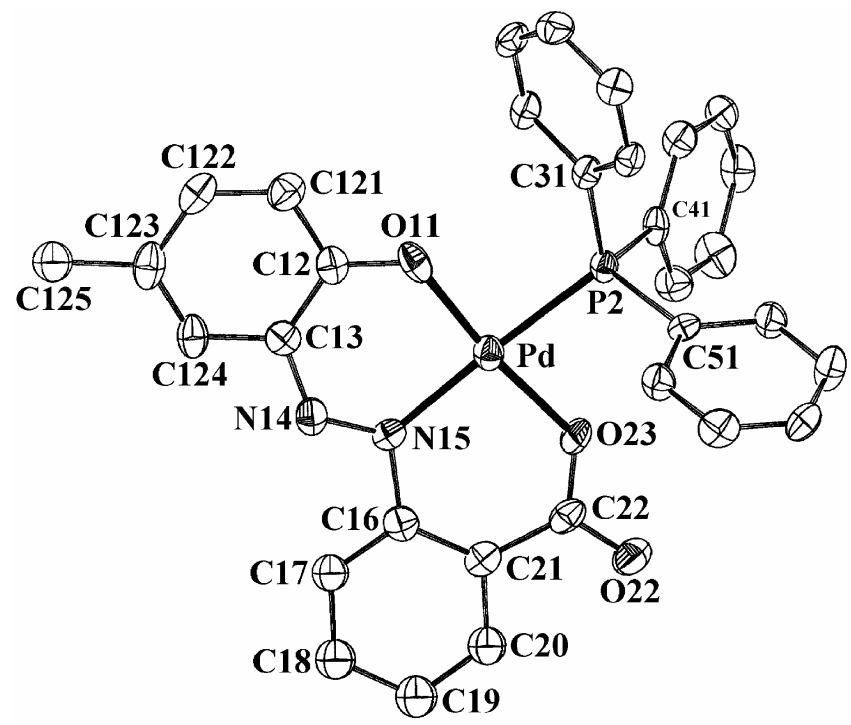

Figure 1. View of the $\left[\mathrm{Pd}\left(\mathrm{PPh}_{3}\right)(\mathrm{L})\right]$ complex.

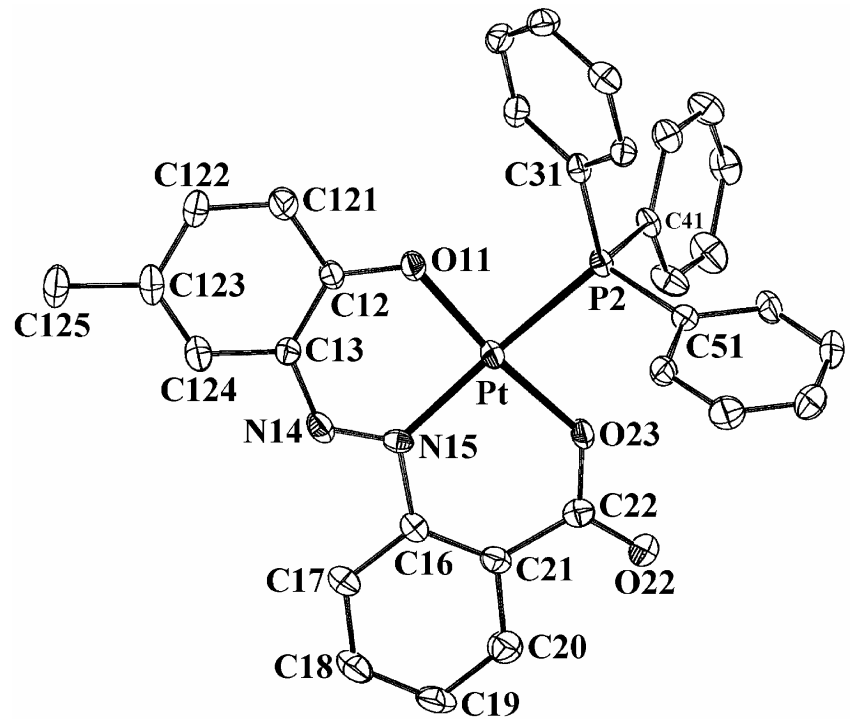

Figure 2. View of the $\left[\mathrm{Pt}\left(\mathrm{PPh}_{3}\right)(\mathrm{L})\right]$ complex. in refluxing ethanol in the presence of triethylamine to afford the expected mixed-ligand palladium complex, viz. $\left[\mathrm{Pd}\left(\mathrm{PPh}_{3}\right)(\mathrm{L})\right]$, in a decent yield. The analogous platinum complex, $\left[\operatorname{Pt}\left(\mathrm{PPh}_{3}\right)(\mathrm{L})\right]$, has been obtained from a similar reaction of ligand 1 with cis$\left[\mathrm{Pt}\left(\mathrm{PPh}_{3}\right)_{2} \mathrm{Cl}_{2}\right]$. The observed elemental $(\mathrm{C}, \mathrm{H}, \mathrm{N})$ analytical data of the two complexes are found to be consistent with their compositions. Formulation of these complexes indicates that in both of them ligand $\mathbf{1}$ is probably coordinated to the metal center as a dianionic tridentate $\mathrm{O}, \mathrm{N}, \mathrm{O}$-donor (2). In order to verify the binding mode of ligand $\mathbf{1}$ in these two complexes, structures of both the complexes have been determined by X-ray crystallography. The structures are shown in figures 1 and 2 , and some relevant bond parameters are presented in table 2 . Both structures are similar and it may be noted here that though the palladium and platinum starting materials have different geometries, they have afforded complexes of similar composition and stereochemistry. In each complex the ligand $\mathbf{1}$ is coordinated to the metal center in the expected tridentate fashion (2). A triphenylphosphine is also coordinated to each metal center. The central metal ion is thus sitting in a $\mathrm{NO}_{2} \mathrm{P}$ coordination sphere in both the complexes, which is distorted significantly from ideal square-planar geometry, as reflected in all the bond parameters around the metal centers. The $\mathrm{M}-\mathrm{N}, \mathrm{M}-\mathrm{O}$ and $\mathrm{M}-\mathrm{P}(\mathrm{M}=$ $\mathrm{Pd}$ and $\mathrm{Pt}$ ) distances are all quite normal, and so are the phenolic $\mathrm{C}-\mathrm{O}$, carboxylate $\mathrm{C}-\mathrm{O}$ and azo $\mathrm{N}-\mathrm{N}$ distances within the coordinated ligand $\mathbf{1}$. $^{2,6}$

\section{$3.2{ }^{1} H$ NMR spectra}

${ }^{1} \mathrm{H}$ NMR spectra of both the $\left[\mathrm{M}\left(\mathrm{PPh}_{3}\right)(\mathrm{L})\right](\mathrm{M}=\mathrm{Pd}$ and $\mathrm{Pt}$ ) complexes have been recorded in $\mathrm{CDCl}_{3}$ solution. In the palladium complex broad signals are observed within 7.3-7.7 ppm due to the coordinated $\mathrm{PPh}_{3}$ ligand. The methyl signal of the O,N,Ocoordinated ligand $(\mathrm{L})$ is observed at $2.30 \mathrm{ppm}$ and out of the seven expected aromatic proton signals for this ligand, five are clearly observed at $6.34(d$, $J=8.6),{ }^{7} 7.06(d, J=10.8), 7.60(s), 7.82(d, J=9.3)$ and $8.34(d, J=9 \cdot 1) \mathrm{ppm}$. The other two expected triplets from the L ligand could not be identified, because of their overlap with the $\mathrm{PPh}_{3}$ signals. In the platinum complex the broad $\mathrm{PPh}_{3}$ signals are observed within 7.4-7.8 ppm. Out of the expected signals for the ligand $\mathrm{L}$, the methyl signal is observed at $2.35 \mathrm{ppm}$ and four aromatic proton signals are observed at $6.35(d, J=8.8), 7.18(d, J=9.0), 8.08(d, J=7.6)$ 
Table 2. Selected bond lengths $(\AA)$ and angles $\left(^{\circ}\right)$ for $\left[\operatorname{Pd}\left(\mathrm{PPh}_{3}\right)(\mathrm{L})\right]$ and $\left[\operatorname{Pt}\left(\mathrm{PPh}_{3}\right)(\mathrm{L})\right]$.

\begin{tabular}{llll}
\hline$\left[\mathrm{Pd}\left(\mathrm{PPh}_{3}\right)(\mathrm{L})\right]$ & & \multicolumn{2}{c}{$\left[\mathrm{Pt}\left(\mathrm{PPh}_{3}\right)(\mathrm{L})\right]$} \\
\hline Bond lengths $(\AA)$ & & $\mathrm{Pt}-\mathrm{O}(11)$ & \\
$\mathrm{Pd}-\mathrm{O}(11)$ & $1.924(5)$ & $\mathrm{Pt}-\mathrm{N}(15)$ & $2 \cdot 964(6)$ \\
$\mathrm{Pd}-\mathrm{N}(15)$ & $2 \cdot 043(4)$ & $\mathrm{Pt}-\mathrm{O}(23)$ & $1 \cdot 952(6)$ \\
$\mathrm{Pd}-\mathrm{O}(23)$ & $1 \cdot 987(4)$ & $\mathrm{Pt}-\mathrm{P}(2)$ & $2 \cdot 2878(18)$ \\
$\mathrm{Pd}-\mathrm{P}(2)$ & $2 \cdot 2938(15)$ & $\mathrm{C}(12)-\mathrm{O}(11)$ & $1 \cdot 307(9)$ \\
$\mathrm{C}(12)-\mathrm{O}(11)$ & $1 \cdot 297(7)$ & $\mathrm{N}(14)-\mathrm{N}(15)$ & $1 \cdot 272(9)$ \\
$\mathrm{N}(14)-\mathrm{N}(15)$ & $1 \cdot 260(6)$ & $\mathrm{C}(22)-\mathrm{O}(22)$ & $1 \cdot 236(11)$ \\
$\mathrm{C}(22)-\mathrm{O}(22)$ & $1 \cdot 227(7)$ & & $1 \cdot 294(10)$ \\
$\mathrm{C}(22)-\mathrm{O}(23)$ & $1 \cdot 296(7)$ & $\mathrm{O}(11)-\mathrm{Pt}-\mathrm{N}(15)$ & \\
$\mathrm{Bond}$ angles $\left({ }^{\circ}\right)$ & & $\mathrm{N}(15)-\mathrm{Pt}-\mathrm{O}(23)$ & $93 \cdot 1(2)$ \\
$\mathrm{O}(11)-\mathrm{Pd}-\mathrm{N}(15)$ & $93 \cdot 34(18)$ & $\mathrm{O}(11)-\mathrm{Pt}-\mathrm{O}(23)$ & $173 \cdot 3(2)$ \\
$\mathrm{N}(15)-\mathrm{Pd}-\mathrm{O}(23)$ & $93.53(18)$ & $\mathrm{N}(15)-\mathrm{Pt}-\mathrm{P}(2)$ & $177 \cdot 10(17)$ \\
$\mathrm{O}(11)-\mathrm{Pd}-\mathrm{O}(23)$ & $173 \cdot 09(18)$ & & \\
$\mathrm{N}(15)-\mathrm{Pd}-\mathrm{P}(2)$ & $177 \cdot 61(13)$ & & \\
\hline
\end{tabular}

Table 3. Electronic spectral data in dichloromethane solution.

\begin{tabular}{lc}
\hline Compound & Electronic spectral data $\lambda_{\max }(\mathrm{nm})\left(\varepsilon / \mathrm{M}^{-1} \mathrm{~cm}^{-1}\right)$ \\
\hline$\left[\mathrm{Pd}\left(\mathrm{PPh}_{3}\right)(\mathrm{L})\right]$ & $548(3100), 361 *(5200), 293(10400)$ \\
{$\left[\mathrm{Pt}\left(\mathrm{PPh}_{3}\right)(\mathrm{L})\right]$} & $581(3400), 551(3700), 386(5800), 339(6500)$ \\
\hline
\end{tabular}

*Shoulder

and $8.41(d, J=9.3) \mathrm{ppm}$, while detection of two triplets and a singlet has not been possible because of overlap problem. ${ }^{31} \mathrm{P}$ NMR spectra of both the $\left[\mathrm{M}\left(\mathrm{PPh}_{3}\right)(\mathrm{L})\right](\mathrm{M}=\mathrm{Pd}$ and $\mathrm{Pt})$ complexes have also been recorded in $\mathrm{CDCl}_{3}$ solution. A clean signal is observed at $20.67 \mathrm{ppm}$ for the palladium complex and at $22.07 \mathrm{ppm}$ for the platinum complex.

\subsection{IR spectra}

Infrared spectra of both the $\left[\mathrm{M}\left(\mathrm{PPh}_{3}\right)(\mathrm{L})\right](\mathrm{M}=\mathrm{Pd}$ and $\mathrm{Pt}$ ) complexes are similar. Each complex shows several sharp bands of different intensities in the $1700-400 \mathrm{~cm}^{-1}$ region. Assignment of each individual band to a specific vibration has not been attempted. However, three sharp and strong bands observed near 1630, 1483 and $1390 \mathrm{~cm}^{-1}$ in both the complexes are attributable respectively to the coordinated carboxylate, azo $(-\mathrm{N}=\mathrm{N}-)$ and phenolic $\mathrm{C}-\mathrm{O}$ fragments. In the uncoordinated 2-(2'-carboxyphenylazo)-4-methylphenol these bands are observed at 1701,1593 and $1402 \mathrm{~cm}^{-1}$ respectively. The observed shift is attributable to complexation. Three strong bands observed near 750, 695 and $530 \mathrm{~cm}^{-1}$ in both the complexes are attributable to the coordinated $\mathrm{PPh}_{3}$ ligand.

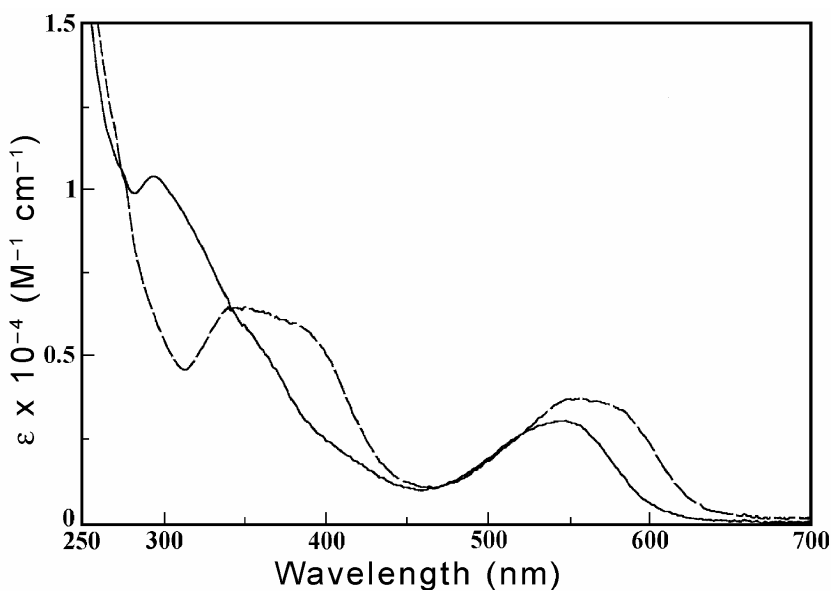

Figure 3. Electronic spectra of the $\left[\mathrm{Pd}\left(\mathrm{PPh}_{3}\right)(\mathrm{L})\right]$ complex $(-)$ and the $\left[\mathrm{Pt}\left(\mathrm{PPh}_{3}\right)(\mathrm{L})\right]$ complex (------) in dichloromethane solution.

\subsection{Electronic absorption spectra}

The $\left[\mathrm{Pd}\left(\mathrm{PPh}_{3}\right)(\mathrm{L})\right]$ and $\left[\mathrm{Pt}\left(\mathrm{PPh}_{3}\right)(\mathrm{L})\right]$ complexes are soluble in dichloromethane, chloroform, acetone, acetonitrile, etc. producing reddish-purple and violet solutions respectively. Electronic spectra of these complexes have been recorded in dichloromethane solutions. Each complex shows several intense absorptions in the visible and ultraviolet regions. Spectral 
Table 4. Composition of molecular orbitals.

\begin{tabular}{lcccccccc}
\hline & \multirow{7}{c}{$\begin{array}{c}\text { \% Contribution of fragments to } \\
\text { Contributing } \\
\text { fragments }\end{array}$} & HOMO & HOMO-1 & HOMO-2 & HOMO-3 & LUMO & LUMO + 1 & LUMO + 2 \\
\cline { 3 - 9 }$\left[\operatorname{Pd}\left(\mathrm{PPh}_{3}\right)(\mathrm{L})\right]$ & $\mathrm{Pd}$ & 78 & 88 & 78 & 71 & 12 & 1 & 0 \\
& $\mathrm{~L}$ & 18 & 11 & 21 & 27 & $87(N=N 49)$ & 99 & 100 \\
{$\left[\mathrm{Pt}\left(\mathrm{PPh}_{3}\right)(\mathrm{L})\right]$} & $\mathrm{Pt}$ & 65 & 47 & 43 & 55 & 10 & 2 & 0 \\
& $\mathrm{~L}$ & 30 & 50 & 53 & 45 & $87(N=N 49)$ & 97 & 100 \\
\hline
\end{tabular}
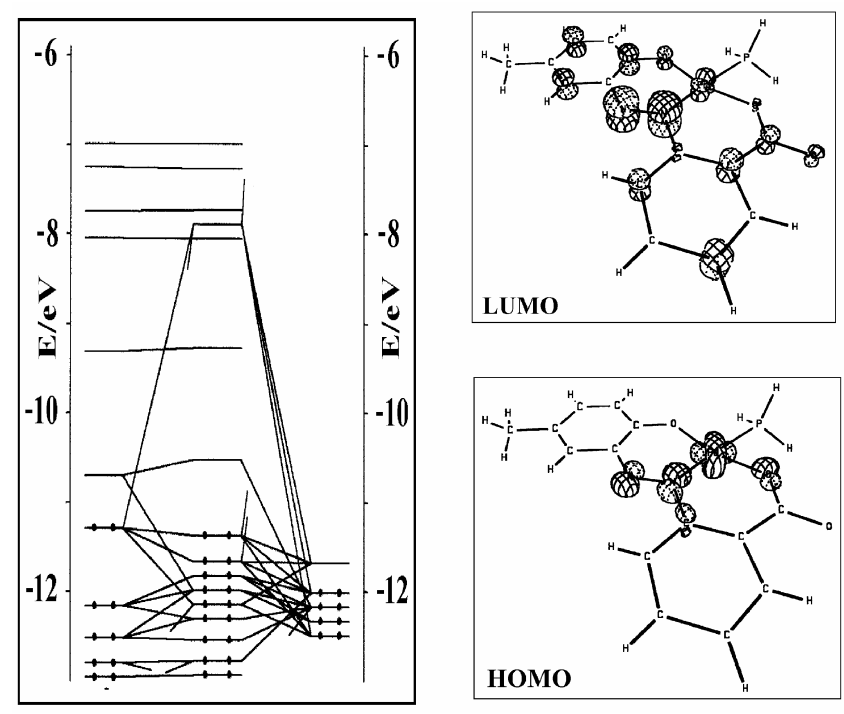

Figure 4. Partial molecular orbital diagram of the $\left[\mathrm{Pd}\left(\mathrm{PPh}_{3}\right)(\mathrm{L})\right]$ complex.

data are given in table 3 and the spectra are shown in figure 3 . While the absorptions in the ultraviolet region are assignable to transitions within the ligand orbitals, origin of those in the visible region was not clear. To have a better understanding of the nature of absorptions in the visible region, qualitative EHMO calculations have been performed on computergenerated models of both the complexes, ${ }^{8}$ where the phenyl rings of the triphenylphosphines have been replaced by hydrogens. The results are found to be qualitatively similar for both the complexes. Compositions of selected molecular orbitals are given in table 4. A partial MO diagram for the $\left[\mathrm{Pd}\left(\mathrm{PPh}_{3}\right)(\mathrm{L})\right]$ complex is shown in figure 4 . The highest occupied molecular orbital (HOMO) and the next three filled orbitals (HOMO-1, HOMO-2 and HOMO-3) have major contributions from the metal d-orbitals. ${ }^{9}$ The lowest unoccupied molecular orbital (LUMO) is localized almost entirely on the $\mathrm{O}, \mathrm{N}, \mathrm{O}$-donor ligand (L) and is concentrated largely on the azo $(\mathrm{N}=\mathrm{N})$ fragment. The next two vacant orbitals (LUMO + 1 and LUMO + 2) are localized on other parts of the same ligand (L). The lowest energy absorption in the visible region is therefore assignable to an allowed transition from the filled metal d-orbital (HOMO) to the vacant $\pi^{*}(\mathrm{azo})$-orbital of the L ligand (LUMO). It is relevant to note here that such metal-to-lignad charge-transfer transition is relatively less common in complexes of palladium and platinum. ${ }^{10}$ The other absorptions in the visible region may be assigned to similar charge-transfer transitions from the filled metal $d$-orbitals to the vacant ligand (L) orbitals.

\section{Conclusions}

The present study shows that 2-(2'-carboxyphenylazo)-4-methylphenol $\left(\mathrm{H}_{2} \mathrm{~L}, 1\right)$ can readily coordinate a metal ion in the dianionic tridentate $\mathrm{O}, \mathrm{N}, \mathrm{O}$-fashion (2) via dissociation of the two acidic protons. This is manifested in the formation of the stable mixed-ligand complexes of palladium and platinum of type $\left[\mathrm{M}\left(\mathrm{PPh}_{3}\right)(\mathrm{L})\right](\mathrm{M}=\mathrm{Pd}$ and $\mathrm{Pt})$. Attempts to bind this ligand (1) to other platinum group of metals in the same tridentate fashion (2) leading to the formation of interesting homoleptic and heteroleptic complexes are currently in progress.

\section{Supplementary material}

Crystallographic data for the $\left[\mathrm{Pd}\left(\mathrm{PPh}_{3}\right)(\mathrm{L})\right]$ and $\left[\mathrm{Pt}\left(\mathrm{PPh}_{3}\right)(\mathrm{L})\right]$ complexes in the CIF format have been deposited with the Cambridge Crystallographic Data Center, CCDC No. 614148 for the $\left[\mathrm{Pd}\left(\mathrm{PPh}_{3}\right)(\mathrm{L})\right]$ complex and 614147 for the $\left[\operatorname{Pt}\left(\mathrm{PPh}_{3}\right)(\mathrm{L})\right]$ complex.

\section{Acknowledgements}

Financial assistance received from the UGC-CAS Program of the Department of Chemistry, Jadavpur University, is gratefully acknowledged. MGBD 
thanks Engineering and Physical Sciences Research Council (EPSRC) (UK) and the University of Reading for funds for the Image Plate System. SH thanks the University Grants Commission (UGC), New Delhi for fellowship [Grant No. 10-2(5)2004(1)E.U.II].

\section{References}

1. (a) Wheate N J and Collins J G 2003 Coord. Chem. Rev. 241 133; (b) Quiroga A G and Ranninger C N 2004 Coord. Chem. Rev. 248 119; (c) Canovese L, Chessa G, Visentin F and Uguagliati P 2004 Coord. Chem. Rev. 248 945; (d) Slagt M Q, van Zwieten D A P, Moerkerk A J C M, Klein Gebbink R J M and van Koten G 2004 Coord. Chem. Rev. 248 2275; (e) Bedford R B, Cazin C S J and Holder D 2004 Coord. Chem. Rev. 248 2283; (f) Moiseev I I and Vargaftik M N 2004 Coord. Chem. Rev. 248 2381; (g) Silverman E E, Cardolaccia T, Zhao X, Kim K-Y, Haskins-Glusac K and Schanze K S 2005 Coord. Chem. Rev. 249 1491; (h) Ma B, Djurovich P I and Thompson M E 2005 Coord. Chem. Rev. 249 1501; (i) Trzeciak A M and Ziólkowski J J 2005 Coord. Chem. Rev. 249 2308; (j) van Zutphen S and Reedijk J 2005 Coord. Chem. Rev. 249 2845; (k) Jain V K and Jain L 2005 Coord. Chem. Rev. 249 3075
2. (a) Dutta S, Basu P and Chakravorty A 1991 Inorg. Chem. 30 4031; (b) Chakravarty, J, Dutta S, Chandra S K, Basu P and Chakravorty A 1993 Inorg. Chem. 324249

3. Sinha P K, Falvello L R and Bhattacharya S 2004 Indian J. Chem. A43 1846

4. (a) Hertley F R 1973 The chemistry of palladium and platinum (ed.) P L Robinson (London: Applied Science) 14 458; (b) Malatesta L and Angoletta M 1957 J. Chem. Soc. 1186

5. Sheldrick G M 1997 SHELXS-97 and SHELXL-97: Program for solution and refinement of crystal structures (Germany: University of Gottingen)

6. (a) Shimazaki $Y$, Tashiro M, Motoyama $T$, Iwatsuki S, Yajima T, Nakabayashi Y, Naruta Y and Yamauchi O 2005 Inorg. Chem. 44 6044; (b) Jones N D, Meessen P, Losehand U, Patrick B O and James B R 2005 Inorg. Chem. 443290

7. Multiplicity of the signals along with the coupling constant (in $\mathrm{Hz}$ ) are given in parentheses

8. (a) Mealli C and Proserpio D M $1990 \mathrm{~J}$. Chem. Edu. 67 399; (b) Mealli C and Proserpio D M 1994 CACAO Version 4.0, Firenze, Italy

9. Contribution of the metal center to HOMO, HOMO-1, HOMO-2 and HOMO-3 is slightly less in the platinum complex

10. (a) Dey S, Jain V K, Knodler A, Klein A, Kaim W and Zalis S 2002 Inorg. Chem. 41 2864; (b) Song D, Wu Q, Hook A, Kozin I and Wang S 2001 Organometallics 204683 